\title{
BRAND PRODUCTS OF REGIONAL CUISINE IN THE PROMOTION OF TOURISM IN ROZTOCZE
}

\author{
EWA BEKIER-JAWORSKA ${ }^{1}$, MARCIN BOCHENEK ${ }^{2}$ \\ ${ }^{1}$ State Higher School of Vocational Education in Zamość, Institute of Tourism and Recreation \\ ${ }^{2} J o ́ z e f$ Piłsudski University of Physical Education in Warsaw, Faculty of Physical Education and Sport \\ in Biała Podlaska, Chair of Physical Education
}

\author{
Mailing address: Marcin Bochenek, Faculty of Physical Education and Sport, Chair of Physical Education, \\ 2 Akademicka Street, 21-500 Biała Podlaska, tel.: +48 83 3428724, fax: +48 833428800 , \\ e-mail: marcin.bochenek@awf-bp.edu.pl
}

\begin{abstract}
Introduction. There has been a trend over the last few years of using specialties of regional cuisine as an independent tourist attraction. The creation of local brands is an important element in the promotion of a given region and it also influences the development of culinary tourism. The aim of the studies conducted was to identify regional dishes a choice of dishes that could be described as 'brand dishes' and the use of those dishes as tourist attractions in Roztocze. Material and methods. Studies were conducted on a group of students studying tourism and recreation at State Higher School of Vocational Education (PWSZ) in Zamość using a questionnaire. Results. The questionnaire provided an assessment of the levels of knowledge of regional cuisine among Polish and Ukrainian students, identified the most characteristic dishes and selected brand products, and helped to arrive at a suitable method of promotion. Conclusions. Nationality, family customs and selection of local restaurants highly influence knowledge of regional cuisine. Interviewees decided that the most outstanding products from Roztocze were Zwierzyniec beer, and Biłgoraj pie. Regional products should be used as a tourist attraction in Roztocze.
\end{abstract}

Key words: tourist brand product, regional cuisine, promotion, culinary tourism

\section{Introduction}

Culinary cuisine in Poland is currently strongly promoted by traditional and electronic media (blogs, websites). Tourists are shown places in which the products are produced. Tourist paths leading to production facilities are available [1].

In the context of tourism in Poland, regional cuisine specialties are starting to be considered separate tourist attractions. Traditional products and regional dishes can be a part of a unique tourist service, or be a client magnet by themselves [2].

The authenticity, quality, the connection to the region, and its long tradition of production are the features that are often emphasized in trip programs and leaflets advertising restaurants, inns, or cities and regions in general $[3,4]$.

Brand products are an important feature of the promotion of the region. A local brand is a source of information for consumers and tourists showing that the product is authentic - it is a guarantee of origin and the method of production. This gives the product an identity associated with a specific place and producer. A regional product brand can create an attractive image of an area and contribute to the development of tourism and agritourism [5, 6, 7, 8]. The brand of the Roztocze region is based on a marketing strategy developed by Roztocze Local Tourist Organization. The concept of the brand includes many actions leading to the increase of the region's recognizability for tourists and fulfilling the promise of healthy and active leisure in the bosom of nature. The Roztocze brand is also used for the promotion of local foods [9]. The building of the brand is based on the cultural heritage of the region and the creation of new touristic products in Roztocze, and is also a part of the Develop-ment Strategy of the Lubelskie Voivodeship planned for 2014-2020 (and possibly up to 2030) [10].

The aim of the research conducted was to identify regional dishes, a choice of dishes that could be described as 'brand dishes' and the use of those dishes as tourist attractions in Roztocze.

\section{Material and methods}

The research concerned the choice of regional products based on suggested examples and respondents' personal opinions. Studies also identified the most characteristic regional dishes which could, alongside brand dishes, be used for the promotion of tourism in Roztocze. The source of data used in the research was the information collected from students studying tourism and recreation at PWSZ in Zamość, by means of a questionnaire. The research included Polish and Ukrainian students and studies were conducted in 2013. The research group constituted students studying tourism and recreation who, in the future, will become active agents in the field of tourism in the region. The questionnaire was intended to assess their knowledge and opinions of regional cuisine. Respondents were asked to choose brand products and the best ways of promoting them. In order to demonstrate the connection between knowledge of cuisine and nationality, the research was also conducted on Ukrainian students.

The questionnaire used in the research contained 18 questions and included factors such as gender, age, nationality, place of residence and material situation, which highly influence knowledge of regional cuisine $[11,12,13,14]$. In order to identify the most characteristic dishes of Roztocze and choose 
the products of regional cuisine that could be considered brand products, open questions were used. In order to establish a method of promotion of brand tourist products, a cafeteria survey was used with multi-option, half-open questions. Other questions included in the questionnaire were multi-option and close-end. In total 196 people were questioned, including 130 women $(66 \%)$ and 66 men (34\%). Most respondents were between 18 and $25-176$ people (90\%), fewer people were under $18(9.5 \%)$ or 26 and over $(0.5 \%)$. Among the questioned group Polish nationality was declared by 104 people (53\%), and Ukrainian by 91 people (46.5\%). Only one person was PolishUkrainian (0.5\%). By analyzing the place of residence of students, it was established that most respondents came from cities of up to 50000 residents (36\%) and from the countryside (33\%). $21 \%$ of respondents lived in cities with over 50000 residents. The smallest group consisted of students from towns with fewer than 5000 residents (10\%). In the research, the material situation of the respondents was also included. Most people described their material status as good (55\%) or average (35\%). According to 11 people (5\%), their material status was very good and for 10 people (5\%) it was bad.

\section{Results}

A significantly important element in the assessment of knowledge of regional cuisine was the parentage of the respondents. $44 \%$ of the respondents declared their permanent residence in Roztocze, and 56\% lived there mostly to finish college.

When asked to assess their knowledge of regional cuisine most students described their knowledge as average $(41 \%)$ or good (38\%). 12\% admitted they did not know anything about regional cuisine and 9\% described their knowledge as very good.

Family home and cultivated traditions, as well as widely understood promotion of local specialties and their availability to both locals and tourists, influence knowledge of regional cuisine. The places in which the respondents had the opportunity to consume regional dishes is shown in figure 1.

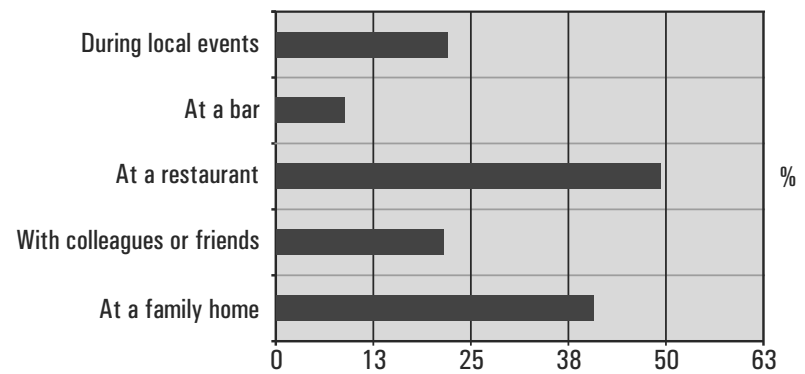

* - the figures do not add up to $100 \%$ as respondents could choose more than one answer.

Figure 1. The place of consumption of regional dishes of Roztocze

$$
/ \mathrm{N}=196 /
$$

In order to identify the most characteristic dishes of Roztocze, respondents were asked to name a few based on free association. In the analysis of dishes named by the students in the questionnaire as local specialties of Roztocze, only those dishes, which were named six or more times were included. Others were rejected as not very well known, or not connected to the region.

According to Polish and Ukrainian students, the most well- known dish in Roztocze is dumplings. This is a dish made of thin dough in which stuffing is wrapped. The stuffing is mostly made out of curd cheese and potatoes, buckwheat, cabbage and mushrooms or local fruit. Other dishes associated with Roztocze cuisine by both tested groups were sauerkraut stew and sour rye soap. Compared to the Ukrainian students, the Polish group identified more dishes associated with Roztocze (tab. 1).

Table 1. The most characteristic dishes of regional cuisine in Roztocze according to students

\begin{tabular}{|l|c|c|l|c|c|}
\hline \multicolumn{2}{|c|}{ Opinion of Polish students $/ \mathbf{N}=104 \mid$} & \multicolumn{3}{c|}{ Opinion of Ukrainian students /N=91/ } \\
\hline \multicolumn{1}{|c|}{ Dish } & $\mathbf{N}^{*}$ & $\%$ & \multicolumn{1}{|c|}{ Dish } & $\mathbf{N}^{*}$ & $\%$ \\
\hline Dumplings & 56 & 53.85 & Dumplings & 31 & 34.07 \\
\hline Biłgoraj pie & 36 & 34.62 & Sauerkraut stew & 24 & 26.37 \\
\hline Sauerkraut stew & 19 & 18.27 & Sour rye soap & 22 & 24.18 \\
\hline Regional beer & 19 & 18.27 & Red borscht & 6 & 6.59 \\
\hline 'Cebularz' & 18 & 17.31 & & & \\
\hline Potato pancakes & 18 & 17.31 & & & \\
\hline Stuffed cabbage & 13 & 12.50 & & & \\
\hline Sour rye soap & 7 & 6.73 & & & \\
\hline White borscht & 6 & 5.77 & & & \\
\hline
\end{tabular}

* - only dishes that were chosen six or more times were included in the results.

In the promotion of regional cuisine, the brand of the product is as important as knowledge of local specialties. Four renowned products were chosen in the research: Biłgoraj pie, bean and rape honey from Roztocze [15], Roztocze holiday oil [16] and Zwierzyniec beer. The following criteria were important in making a choice: the tradition of production, its presence on the List of Traditional Products of the Lubelskie Voivodeship [17], the presence of the products at local events, their availability to tourists, and their quality (prizes and awards won). Students' knowledge of those products was varied (tab. 2). The most well-known brand product turned out to be Zwierzyniec beer. The second was Biłgoraj pie.

Table 2. Knowledge of regional brand products in Roztocze /N=196/

\begin{tabular}{|l|c|c|c|c|}
\hline \multirow{2}{*}{ Name of the product } & \multicolumn{2}{|c|}{ Known products } & \multicolumn{2}{c|}{$\begin{array}{c}\text { Known and consumed } \\
\text { products }\end{array}$} \\
\cline { 2 - 5 } & $\mathbf{N}^{*}$ & $\%$ & $\mathbf{N}^{*}$ & $\%$ \\
\hline Biłgoraj pie & 106 & 54.08 & 77 & 39.29 \\
\hline Bean or rape honey from Roztocze & 39 & 19.90 & 18 & 9.18 \\
\hline Roztocze holiday oil & 51 & 26.02 & 38 & 19.39 \\
\hline Zwierzyniec beer & 160 & 81.63 & 137 & 69.90 \\
\hline
\end{tabular}

* - respondents could mark more than one answer.

When asked if regional cuisine can be used in the promotion of tourism in Roztocze, most of the students (72\%) answered yes. $69 \%$ of respondents had positive responses to high-quality brand products. According to $77 \%$ of respondents, brand products can be a tourist attraction and increase the number of tourists visiting the area.

Among four of the products mentioned above, Zwierzyniec beer and Biłgoraj pie were identified as the biggest attraction of the regional cuisine of Roztocze. Less significant products were bean and rape honey and Roztocze holiday oil (fig. 2). 


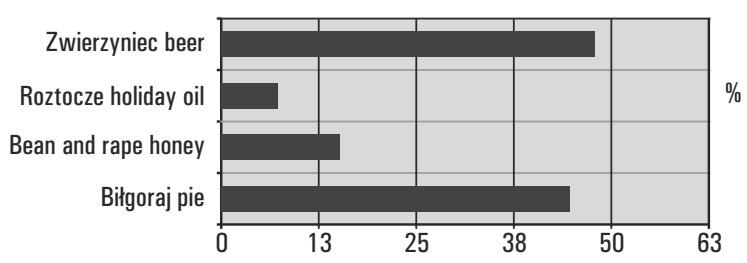

* - the figures do not add up to $100 \%$ as respondents could choose more than one answer.

Figure 2. The attractiveness of brand products of regional cuisine of Roztocze /N=196/

Other local dishes can also be used in the promotion of the region and be representative of it. Therefore, students were asked to name other dishes that could become brand products of Roztocze. According to respondents, dumplings could be one of those dishes. Other very popular dishes that, according to the respondents, Roztocze can be proud of a sauerkraut stew, sour rye soap, 'tarciuch', cabbage stuffed with buckwheat, 'cebularz' and trout. Products that, according to the respondents, could become brand products are shown in table 3 .

Table 3. Products of Roztocze regional cuisine that. according to the respondents. could be considered brand products / $\mathrm{N}=196 /$

\begin{tabular}{|l|c|c|}
\hline \multicolumn{1}{|c|}{ Product } & $\mathbf{N}^{*}$ & $\%$ \\
\hline Dumplings & 32 & 16.33 \\
\hline Sauerkraut stew & 24 & 12.24 \\
\hline Sour rye soap & 24 & 12.24 \\
\hline 'Tarciuch' & 13 & 6.63 \\
\hline 'Cebularz' & 10 & 5.10 \\
\hline Cabbage stuffed with buckwheat & 8 & 4.08 \\
\hline Trout & 6 & 3.06 \\
\hline
\end{tabular}

* - only dishes that were chosen six or more times were included in the results.

$64 \%$ of respondents declared that travel agencies should offer trips to places of production of regional specialties, combined with tastings. This would allow visitors to familiarize themselves with the process of production of products and the quality of the stock, and enable them to buy specialties directly from the producer.

In order to encourage tourists to undertake culinary trips, local specialties should be promoted. The research shows that the best way to do this is the placement of information and adverts on the Internet and on television. Media like radio and press hold less significance. There are also other means of promotion, such as culinary shows and tastings of dishes at varied local and national events (fig. 3).

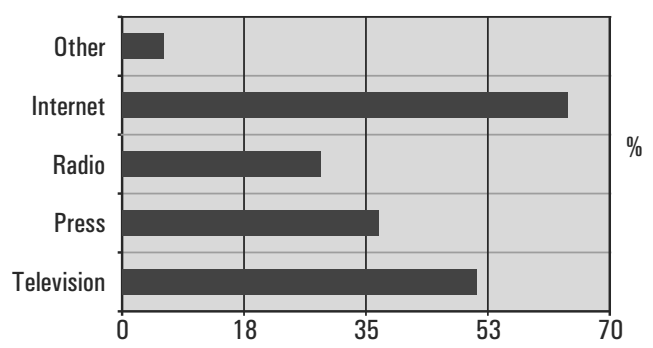

* - The figures do not add up to $100 \%$ as respondents could choose more than one answer.

Figure 3. The method of promotion of brand products of Roztocze $/ \mathrm{N}=196 /$
Analysis of the knowledge of regional cuisine in Polish and Ukrainian groups of students shows significant statistical differences. The biggest percentage of respondents from Poland and Ukraine described their knowledge of this topic as average. However Polish students are more knowledgeable about their native cuisine. A very good level of knowledge was declared by $11.4 \%$ of Poles and $6.6 \%$ of Ukrainians. A lack of knowledge of regional cuisine was declared by $4.8 \%$ of Poles and $18.7 \%$ of Ukrainians (tab. 4).

Table 4. Knowledge of regional cuisine among Polish and Ukrainian students

\begin{tabular}{|l|c|c|c|c|}
\hline \multirow{2}{*}{ Category of answers } & \multicolumn{2}{|c|}{ Polish } & \multicolumn{2}{c|}{ Ukraine } \\
\cline { 2 - 5 } & $\mathbf{N}^{*}$ & $\%$ & $\mathbf{N}^{*}$ & $\%$ \\
\hline Very good & 12 & 54.08 & 77 & 39.29 \\
\hline Good & 41 & 19.90 & 18 & 9.18 \\
\hline Average & 47 & 26.02 & 38 & 19.39 \\
\hline No knowledge & 5 & 81.63 & 137 & 69.90 \\
\hline$?^{2}=10.22$ Сков $0.22 \mathrm{p}<0.02$ & \multicolumn{4}{|l}{} \\
\hline
\end{tabular}

As it turns out, the shaping of culinary habits and traditions, takes place mostly at home. The place where one eats is also an important factor. Polish students, given their place of residence, had much more time and opportunity to get to know the regional cuisine of Roztocze. Analysis of the results shows that statistical differences (no more than $\mathrm{p}<0.001$ ) occur in cases of consuming dishes of this cuisine at home and at various events. In this context Polish students have the advantage. A small percentage of respondents learned about certain Roztocze specialties from family members and friends. In this case the differences between two groups were not statistically significant (tab. 5).

Table 5. The place of consumption of regional cuisine dishes of Roztocze by Polish and Ukrainian students

\begin{tabular}{|c|c|c|c|c|c|c|c|c|}
\hline \multirow{3}{*}{ Category of answer } & \multicolumn{4}{|c|}{ Polish } & \multicolumn{4}{|c|}{ Ukraine } \\
\hline & \multicolumn{2}{|c|}{ N } & \multicolumn{2}{|c|}{$\%$} & \multicolumn{2}{|c|}{$\mathbf{N}$} & \multicolumn{2}{|c|}{$\%$} \\
\hline & No & Yes & No & Yes & No & Yes & No & Yes \\
\hline Family home & 42 & 63 & 40 & 60 & 74 & 17 & 81.3 & 81.7 \\
\hline \multicolumn{9}{|l|}{$x^{2}=34.45$ СKOR $=0.39 p<0.001$} \\
\hline At friends' and colleagues' homes & 84 & 21 & 80 & 20 & 70 & 21 & 76.9 & 23.1 \\
\hline \multicolumn{9}{|c|}{$\mathrm{x}^{2}=0.27 \mathrm{p}<0.5$ kstatistically irrelevant } \\
\hline At restaurants & 63 & 42 & 60 & 40 & 36 & 55 & 39.6 & 60.4 \\
\hline \multicolumn{9}{|l|}{$x^{2}=8.15$ CKOR $=0.20 p<0.005$} \\
\hline In a bar & 92 & 13 & 87.6 & 12.4 & 87 & 4 & 95.6 & 4.4 \\
\hline \multicolumn{9}{|l|}{$x^{2}=3.92$ СКOR $=0.14 p<0.05$} \\
\hline During local events & 86 & 37 & 64.8 & 35.2 & 85 & 6 & 93.4 & 6.6 \\
\hline $\mathrm{x}^{2}=17.97$ СКOR $=0.28 \mathrm{p}<0.001$ & & & & & & & & \\
\hline
\end{tabular}

\section{Discussion}

Knowledge of regional cuisine is a key element in its usage in promotion. Research conducted by Sajdakowska et al. [18] shows that the family home is an important factor in cultivating culinary traditions in the region. This is confirmed by research shown in this publication. However, restaurants hold the greatest significance in that regard. Sanchez-Canizares and others [19] claim that the choice of regional dishes in restaurants is a key element from tourists' points of view. According to the 
authors [19] gastronomy is considered by the visitors as the biggest tourist attraction of Cordoba (76.2\%) and the increasing number of visitors was responsible for the increase in the number of restaurants (from 156 in 1998 to 235 in 2009). According to research conducted in Poland by Citybell Consulting and the ARC Rynek i Opinia research institute, Poles going on holiday domestically mostly visit restaurants serving local cuisine (89\%) and inns (84\%), followed by local breweries (54\%), works producing local foods (37\%), vineyards (33\%) and museums connected to the production of food (26\%) [20]. In the case of Roztocze, there are no publications on the choice of regional dishes served by local restaurants or reviews of their attractions for tourists. There is also no culinary path in Roztocze, which should extend its reach to Roztocze Gorajskie, Roztocze Szczebrzeszyńskie, Roztocze Tomaszowskie, Roztocze Rawskie and neighboring cities such as Zamość and Biłgoraj.

The most characteristic dishes of local cuisine in Roztocze are, according to respondents, dumplings. As Jeżewska-Zychowicz claims [11], the frequency with which one eats is more influential when it comes to knowledge of traditional products than an authentic connection to the region. Research conducted confirms those observations because dumplings, sauerkraut stew and sour rye soap are popular dishes throughout Poland and not just in Roztocze.

Cuisine can and should be a showcase for the region [14, 21]. Brand products are a very important factor, and their identification is a topic of considerable research [21, 22]. The building of a local brand of regional products, according to Byszewska et al. [5], is not only profitable for producers, but could also be an inspiration for the development of tourism and services, especially in regions with unfavorable economic situations. In the group of people questioned about whether they were in favor of usage of brand products in tourist services, $43 \%$ answered 'rather yes' and 32.8\% 'yes'.

According to Byszewska et al. [5], Biłgoraj pie is a famous brand product in the Lubelskie Voivodeship. Similar results were obtained in conducted research, although the most frequently chosen answer was not Biłgoraj pie (38.9\%), but Zwierzyniec beer (41.6\%). Of other brand products bean honey or rape honey from Roztocze were chosen by $13.3 \%$ of the respondents and Roztocze holiday oil only by $6.2 \%$. Those products were also the least well-known (honey - 10.9\%; oil - 14.3\%) and the least consumed (honey $-6.7 \%$; oil $-14 \%$ ) by the respondents. Similar results were obtained by Żakowska-Biemans and Kuc [14], who pointed out that oils and fats (8\%) and honeys, and fruit and vegetable products were the least frequently chosen. Most of the respondents (51\% answered 'rather yes' and $18.4 \%$ 'yes') believed that the products mentioned above are of high quality. As the literature claims, regional foods are associated with high quality $[5,19]$ and taste $[11,14]$.

Aside from four suggested products, respondents were asked about their opinion on what other regional dishes deserve to be described as brand products. According to the respondents dumplings should be the showcase of the region. Similar results in regions other than Roztocze were obtained by Radzymińska et al. [13] and Staniewska et al. [22]. In the case of the secondmost-frequently chosen dish, which was sauerkraut stew, the results are the same, which is also confirmed in specialist literature [11]. According to Buczkowska [23], the creation and promotion of appropriate tourist souvenirs (also based on local foods and drinks) is a key factor in the development of tourist activity in certain places and for visiting tourists. Pomianowski [12] names television adverts as the most effective method and for Staniewska et al. [22] and Grabowska et al. [24] the best method of promotion is the Internet (80\%). Local media, leaflets, brochures and local events are also significant. Student respondents also named the Internet and television as the most significant media in promotion. However, one of the most fre- quently used methods of promotion of regional cuisine in Roztocze is local events such as the Festival of Local Products 'Tastes of Za-mość and Roztocze' organised every year in Zamość as a part of the 'Hetman Fair', Festival of buckwheat and cranberries 'Gryczaki' in Janów Lubelski, the Lubelskie Meetings with Traditional and Hunting Culture in Zwierzyniec, the Imperial and Royal Galician Fair in Narol, and the Festival of Culture and Borderland Food in Basznia Dolna [9].

Plebańczyk [10] describes the showing to tourists of places in which products are created, for example big beer companies in Poland have started to open their breweries to tourists and have created tourist paths through their production facilities. Visitors can tour, taste, and also buy products made in a certain place. Żakowska-Biemans and Kuc [18] also claim that the preferred places to buy traditional and regional foods are, inter alia, specialist shops and directly at the producer's facility. Most respondents (rather yes $-30.7 \%$; yes $-33.8 \%$ ) taking part in the research spoke for the introduction to travel agency trips on the places of production of local foods, combined with the possibility of tasting and purchase. Local travel agencies in Roztocze offer visits to restaurants that specialize in regional cuisine and demonstrations of pressing of oil combined with the possibility of purchase [25].

\section{Conclusions}

1. Family homes and restaurants are important factors in cultivating culinary traditions in a given region.

2. Nationality has an influence on knowledge of regional cuisine.

3. Dumplings, sauerkraut stew, sour rye soap and cabbage stuffed with buckwheat were named the most characteristic traditional dishes in Roztocze.

4. Zwierzyniec beer and Biłgoraj pie turned out to be the most popular brand dishes.

5. Dumplings could also be considered a brand dish.

6. Products of regional cuisine can and should be an important element in the promotion of tourism in Roztocze.

7. Travel agencies should include trips to the places of production of regional specialities, combined with tastings and possibility of purchase.

\section{Literature}

1. Plebańczyk K. (2013). Culinary tourism in the context of balanced development in culture - perspectives for Poland. Turystyka Kulturowa 10, 23-38. [in Polish]

2. Tyran E. (2007). Regional and traditional products as an important part of rural tourism offer. Acta Scientiarum Polonorum. Oeconomia 6(3), 121-128.

3. Borowska A. (2008). Attitudes of European consumers towards traditional and regional products. Zeszyty Naukowe SGGW w Warszawie, Ekonomika i organizacja gospodarki żywnościowej 72, 145-159. [in Polish]

4. Matusiak A. (2009). Culinary travels as an element of cultural tourism. Culinary heritage of Górny Śląsk. Turystyka kulturowa 2, 4-19. [in Polish]

5. Byszewska I., Szczygilski M., Goszczyński W. (2013). Local products - opportunities and challenges. Forum Aktywizacji Obszarów Wiejskich, 4-27. [in Polish]

6. Godlewski G. (2009). Polish tourist brand - products, prospects, strategies. Polish Journal of Sport and Tourism 16(4), 201-208.

7. Kuźniar W. (2010). The role of traditional products in the development of agrotourism (following the example of the Podkarpackie Voivodeship). Acta Scientiarum Polonorum. 
Oeconomia 9(4), 245-254. [in Polish]

8. Radzymińska M., Jakubowska D., Smoczyński S.S. (2009). Local and regional products in the Mrągowskie district. Biuletyn Naukowy 30, 53-56. [in Polish]

9. www.roztoczewita.pl. Retrieved 25.08.2014.

10. www.strategia.lubelskie.pl. Retrieved 25.08.2014.

11. Jeżewska-Zychowicz M. (2009). Chosen activities of young consumers in the traditional foods market and their attitudes. Żywność. Nauka. Technologia. Jakość 3(64), 126-136. [in Polish]

12. Pomianowski J.F. (2009). Consumer research on regional foods. Biuletyn Naukowy 30, 41-47. [in Polish]

13. Radzymińska M., Smoczyński S.S., Staniewska K., Garbowska B., Gątarska A., Jakubowska D. (2009). The market of regional products produced by agrotouristic farms - state and future prospects. Biuletyn Naukowy 30, 57-63. [in Polish]

14. Żakowska-Biemans S., Kuc K. (2009). Traditional and regional foods in the opinion and behavior of Polish consumers. Zywność. Nauka. Technologia. Jakość 3(64), 105-114. [in Polish]

15. www.ulikroztocze.pl. Retrieved 25.08.2014.

16. www.olejarniaswiateczna.pl. Retrieved 25.08.2014.

17. www.minrol.gov.pl. Retrieved 25.08.2014.
18. Sajdakowska M., Żakowska-Biemans S. (2009). The perception of traditional foods by Polish consumers based on qualitative study. Żywność. Nauka. Technologia. Jakość 3(64), 95-104. [in Polish]

19. Sanchez-Canizares M.S., Lopez-Guzman T. (2012). Gastronomy as a tourism resource: profile of the culinary tourist. Current Issues in Tourism 15(3), 229-245.

20. www.egospodarka.pl. Retrieved 25.08.2014.

21. Costa L., Besio K. (2011). Eating Hawai'i local foods and place-making in Hawai'i Regional Cuisine. Social \& Cultural Geography 12(8), 839-854.

22. Staniewska K., Smoczyński S.S. (2009). Identification of local and regional specialities in the Gołdapskie and Węgorzewskie districts. Biuletyn Naukowy 30, 75-78. [in Polish]

23. Buczkowska K. (2014). Local food and beverage products as important tourist souvenirs. Turystyka Kulturowa 1, 47-58.

24. Garbowska B., Smoczyński S. (2009). The image of regional and local products in the Giżyckie and Oleckie districts. Biuletyn Naukowy 30, 131-134. [in Polish]

Submitted: September 15, 2014

Accepted: November 4, 2014 